\title{
Carbon Sequestration in Tropical Forest Stands: Its Control by Plant, Soil and Climatic Factors
}

\author{
K. A. J. M. Kuruppuarachchi ${ }^{1}$, Gamini Seneviratne ${ }^{2}$, Buddhika D. Madurapperuma ${ }^{3}$ \\ ${ }^{1}$ Department of Botany, The Open University of Sri Lanka, Nawala, Sri Lanka \\ ${ }^{2}$ Microbial Biotechnology Unit, Institute of Fundamental Studies, Sri Lanka \\ ${ }^{3}$ Department of Environmental Science and Management, Humboldt State University, Arcata, CA, USA \\ Email: kajmkuruppu@gmail.com
}

Received 12 October 2015; accepted 1 February 2016; published 4 February 2016

Copyright (C) 2016 by authors and Scientific Research Publishing Inc.

This work is licensed under the Creative Commons Attribution International License (CC BY). http://creativecommons.org/licenses/by/4.0/

c) (i) Open Access

\begin{abstract}
This study investigated the relationships amongst floristic, soil and climatic parameters and their control on carbon sequestration (CS) in two selected forest stands of Sri Lanka. Representative sampling sites were selected from the dry zone (Sigiriya forest sanctuary) and the wet zone (Udawattakele forest reserve) of Sri Lanka. Litter and soil samples were collected from each sampling site randomly in monthly intervals to cover an annual cycle. Plant biomass carbon stocks were calculated using standard biomass equations. Soil carbon stocks were determined by chemical oxidation and loss on ignition (LOI) methods. Principle Factor Analysis and multiple regression were used to quantify the relationships among the plants, soil and climatic variables. Plant biomass carbon stocks of the forests were governed by labile and stable $\mathrm{C}$ fractions, soil moisture, and plant diversity. The soil fulvic fraction acts as a focal point of interacting the variables such as soil $\mathrm{N}$, free litter fraction (FLF) and humic fraction. During dry period in the dry zone forest, CS was governed by maximum relative humidity through an atmosphere-floor litter-soil continuum. Air temperature and FLF play a vital role in determining soil $\mathrm{N}$. In addition, MacIntosh distance (U) diversity index showed a significant positive relationship with soil $\mathrm{N}$. The dry zone forests are seen to be more climatic sensitive and vulnerable than the wet zone forests in Sri Lanka due to influence of more climatic parameters that govern the soil organic carbon fractions.
\end{abstract}

\section{Keywords}

Tropical Forests, Carbon Sequestration, Soil Organic Carbon 


\section{Introduction}

The Kyoto protocol mainly summarized the effective ways of reducing greenhouse gases such as $\mathrm{CO}_{2}$, which can ideally be controlled through forest plantation supporting carbon sequestration (CS). Therefore, it is imperative to trace controlling factors of CS in the forest ecosystems, because the factors can then be manipulated in order to improve $\mathrm{C}$ storage in forests. In particular, forests in tropics should be managed to maximize $\mathrm{C}$ retention in aboveground and belowground biomass and to conserve soil C (Beedlow et al., 2004). The multiple associations between traits and ecosystem processes can help to identify predictable trait-service clusters. These clusters depend on traits of plants and soil organisms that underlie nutrient cycling (Bello et al., 2010). Such combined approaches are a crucial step in ecosystem service monitoring and in balancing the delivery of multiple and sometimes conflicting services in ecosystem management.

Studies on CS confirmed that tropical forestry is the most cost-effective greenhouse gas mitigation strategy (Ramachandran et al., 2007). Sri Lanka is recognized as vulnerable to climatic change under the small island category (UNFCCC, 1997; IPCC, 2001) with huge community types due to diversity of rainfall and the elevation (Legg \& Jewell, 1995). Nearly 80\% of the land mass covers the dry zone and the rest are wet and intermediate zones (Panabokke, 1996). The southwestern region in the wet zone is mainly covered by the wet evergreen forest. The dry zone has tropical dry mixed evergreen forests (Bandaratillake, 1996). The forest cover in Sri Lanka is approximately 2.1 million hectares, representing 31\% - 32\% of the total land mass (NPPD, 2002).

Plant functional traits control a variety of forest processes, including soil C storage (De Deyn et al., 2008). The plant traits regulate net soil C storage by controlling $\mathrm{C}$ assimilation, its transfer and storage in the belowground biomass, and its release from soil through respiration, fire, and leaching. However, understanding of these processes is still incomplete. There is a huge knowledge gap for understanding the control of floristic diversity on ecosystem C storage in tropical forests (Clark et al., 2001; IPCC, 2006; Rossi et al., 2009). Therefore, more research is needed to evaluate forest $\mathrm{C}$ pools and their control by floristic, climatic, and edaphic factors. An attempt is made here to recognize the factors, which control and/or contribute to biomass CS in the dry and the wet zone forests. This article studies the relationships among the plant, soil and climatic parameters and their control on CS of selected dry and wet forests of Sri Lanka.

\section{Materials and Method}

\subsection{Study Area}

Representative sampling sites were selected from a dry zone forest (Sigiriya sanctuary) and a wet zone forest (Udawattakele) of Sri Lanka ( $5^{\circ} 54^{\prime} \mathrm{N}-9^{\circ} 52^{\prime} \mathrm{N}$; 79 $\left.39^{\circ} \mathrm{E}-8^{\circ} 53^{\prime} \mathrm{E}\right)$. The Dry Zone Forest (DZF), Sigiriya sanctuary, surrounds the ancient rock fortress of Sigiriya, an archeologically important world heritage site at $150 \mathrm{~m}$ altitude. In the 1990s, it was declared a sanctuary with 5099 hectares and belongs to Ceylonese monsoon forest (Green, 1990). Proximity to Sigiriya wildlife office of Kimbissa was selected as the sampling site (Figure 1).

The Wet Zone Forest (WZF) Udawattakelle national heritage, Sri Lanka lies as a small hill range arising from the north of Kandy Lake on the periphery of the ancient "Temple of Tooth Relic" Kandy-The Kings Palace $\left(7^{\circ} 19^{\prime} \mathrm{N}-80^{\circ} 39^{\prime} \mathrm{E}\right)$. Udawattakelle forest reserve (111 ha) was declared as a sanctuary in 1938 . The sanctuary has been designated as a national Man and Biosphere (MAB) reserve (Green, 1990). Altitudes of the area vary from 500 to $800 \mathrm{~m}$. The forest is an isolated cluster with surrounding land settlements. Udawattakelle is a wet semi-evergreen forest in the central hilly region with high species richness (Pushpakumara \& Hitinayake, 2001) and about 460 plant species including 135 tree species and 11 liana species, of which 9 species are endemic to Sri Lanka (Wedathanthri \& Hitinayake, 1999; Senarathna, 2005). Vegetation comprises dense forest, mostly plantation and secondary formation. A plaque in front of "Senanayake Buddhists hermitage" was selected to lay out permanent sampling plots with a flat terrain.

\subsection{Climate}

Sri Lanka is divided into three climatic zones based on annual rainfall and its distribution: Dry Zone (1250 $1525 \mathrm{~mm}$ ) in parts of the southeast and northwest; Intermediate Zone (1525 - $2280 \mathrm{~mm}$ ); and Wet Zone (2280 $5100 \mathrm{~mm}$ ) mostly in the southwestern parts (Premaratne \& Premalal, 2005). Climatic data for the present study were collected from the nearest meteorological stations (dry zone: Palwehera; wet zone: Katugasthota). Monthly average climatic data for ten years at the dry zone revealed $27.7^{\circ} \mathrm{C}$ as average air temperature, $1380 \mathrm{~mm}$ as 


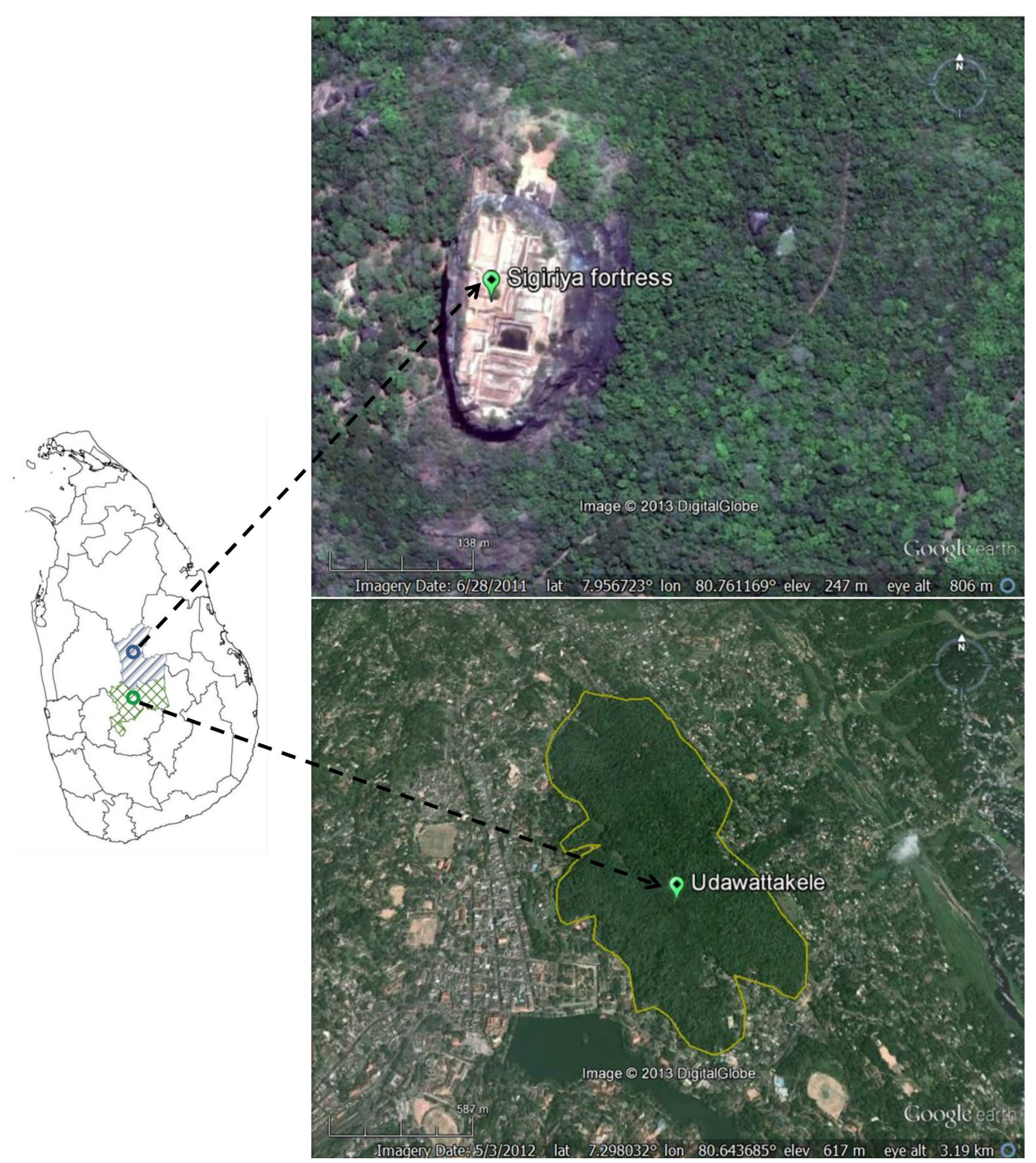

Figure 1. Map of study sites depicting Sigiriya forest sanctuary and Udawattakele forest reserve in Sri Lanka.

annual rainfall, and $79 \%$ as monthly relative humidity. Rainfall pattern of the study period (January-December 2007) slightly deviated from the normal pattern, i.e. inter monsoonal rainfall during March and April was lower in the study period. Northeastern monsoonal rainfall was higher than the normal rainfall. Generally, the dry zone experiences a five-month dry spell from May to end of September. For the Wet zone area, Udawattakelle, climatic conditions include Southwest monsoons from mid-May to July/August and Northeast monsoons October/November to late December. Annual rainfall is $1850 \mathrm{~mm}$ without a prominent dry spell and temperature is around $24^{\circ} \mathrm{C}$ throughout the year (Cramer, 1993; Naoum \& Tsanis, 2003; Petkovsek \& Mikos, 2005).

\subsection{Design of Experimental Plots}

Four sampling plots, $2 \mathrm{~m} \times 2 \mathrm{~m}$, were demarcated randomly in the dry zone forest and the wet zone forest. Around a central square of $1 \mathrm{~m} \times 1 \mathrm{~m}$ of each plot, a trench was dug to a depth of $30 \mathrm{~cm}$ and a width of $15 \mathrm{~cm}$ (Figure 2). A thick polythene sheet was fixed vertically to cut off the fine root growth into the $1 \mathrm{~m} \times 1 \mathrm{~m}$ square, and the trench was filled with soil. A Nylon mesh sized $2 \mathrm{~mm}(2 \mathrm{~m} \times 2 \mathrm{~m})$ was fixed $20 \mathrm{~cm}$ above the plot as a litter-trap. Then, the plot was fenced by thick polythene sheets (black and white) to protect from wild animals 


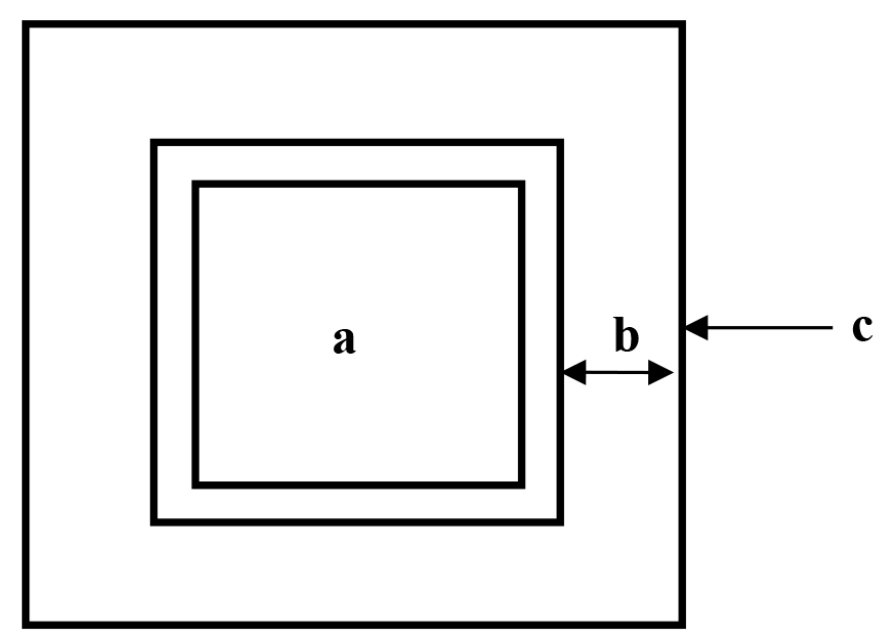

Figure 2. Permanent sampling plot (the layout). Position-a: located in the $1 \mathrm{~m} \times 1 \mathrm{~m}$ square of the plot (no root growth or litterfall). Position-b: located outside the $1 \times 1 \mathrm{~m}$ square (root growth occurs, but no litterfall). Position-c: located outside the $2 \times 2 \mathrm{~m}$ plot (root growth as well as litterfall occur, i.e. forest floor).

and to stop litter movement. A floor litter layer of a $30 \mathrm{~cm} \times 30 \mathrm{~cm}$ in each plot was collected. The remainder of the litter of the plot was removed. The collected litter was oven-dried $\left(65^{\circ} \mathrm{C}\right.$ for $72 \mathrm{hrs}$.), and dry weight was recorded and stored.

\subsection{Soil and Litter Sampling}

Soil and litter samples were collected at monthly intervals to cover a complete annual cycle. Litter accumulation in the litter trap $(2 \mathrm{~m} \times 2 \mathrm{~m})$ was sorted into fine (leaves, flowers etc.) and coarse (woody parts) litter. Initial fresh weight was recorded and then the samples were oven-dried $\left(65^{\circ} \mathrm{C}\right.$ for $72 \mathrm{hrs}$.), weighed and stored. In addition, a litter sample was collected from $30 \mathrm{~cm} \times 30 \mathrm{~cm}$ sharp-edged steel square outside the plot, oven-dried, weighed and stored. Three soil samples were collected using an auger (cross section area $19.6 \mathrm{~cm}^{2}$ ), one from the central square of the $1 \mathrm{~m} \times 1 \mathrm{~m}$ (position-a) and one from outside the $1 \mathrm{~m} \times 1 \mathrm{~m}$ square within the $2 \mathrm{~m} \times 2 \mathrm{~m}$ plot (position-b) to a depth of $25 \mathrm{~cm}$. Another soil core sample was taken to a depth of $25 \mathrm{~cm}$ outside the permanent plot (position-c).

\subsection{Preparation of Soil Samples}

Soil samples were air-dried and sieved $(<2 \mathrm{~mm}$ ). Root fractions (fine roots $<2 \mathrm{~mm}$, and coarse roots $>2 \mathrm{~mm}$ ) were hand-picked, oven-dried, weighed and stored for later analyses. Very fine root fraction was separated by the floating method (Anderson \& Ingram, 1998). The fine root fraction was oven dried at $60^{\circ} \mathrm{C}$ for constant weight (Hodge et al., 2000), and the root biomass was recorded as a percentage of total soil weight. Litter samples were first cleaned with a brush and separated into fine (leaves, flowers and buds) and coarse (twigs, plant materials such as seeds and seed coats) litter. Initial fresh weight was recorded. Then, they were oven dried at $65^{\circ} \mathrm{C}$ to a constant weight and dry weights recorded (Hairiah et al., 2006). Dry samples were ground and stored for further chemical analyses.

\subsection{Soil Analyses}

Soil moisture was determined by oven drying the samples at $105^{\circ} \mathrm{C}$ to a constant weight. Soil $\mathrm{pH}$ was measured using a glass calomel electrode fixed to a pH meter (Schofield and Taylor, 1955) with a soil to water ratio of 1:2. The wet oxidation method without external heating was used to determine $C$ content colorimetrically at $600 \mathrm{~nm}$ by using a UV-Visible spectrophotometer (Walkley, 1934; Walkley \& Black, 1947; Anderson \& Ingram, 1998). Total $\mathrm{N}$ in the soil was determined by using the Micro-Kjeldahl procedure (Bremner \& Tabatabai, 1972). The digestion was performed by heating the sample with concentrated $\mathrm{H}_{2} \mathrm{SO}_{4}$ at $420^{\circ} \mathrm{C}$ for $3 \mathrm{hrs}$. Ammonium- $\mathrm{N}$ 
content in the digest was determined by using Autoanalyzer (Tecator 1030 KjeltecAutoanalyzer) (Bremner \& Tabatabai, 1972). Fractionation of soil C was done by the weight loss on ignition (LOI) method. In this procedure, soil was subjected to sequential thermal oxidation from $100^{\circ} \mathrm{C}$ to $550^{\circ} \mathrm{C}$ using a muffle furnace (Gallenkamp-box furnace F SL-340-0160). Weight loss steps of temperatures between $150^{\circ} \mathrm{C}-200^{\circ} \mathrm{C}, 200^{\circ} \mathrm{C}-400^{\circ} \mathrm{C}$ and $400^{\circ} \mathrm{C}-550^{\circ} \mathrm{C}$ corresponded to oxidation of free soil litter fraction (labile), fulvic fraction (intermediate) and humic fraction (stable) respectively (Evans et al., 2001; Ratnayake et al., 2007).

\subsection{Litter Analyses}

Dry and wet weights of litterfall (coarse and fine litter separately) as well as floor litter layer were recorded in each sampling time and litter density in grams per square meter was calculated (Hairiah et al., 2006). Annual litterfall was then calculated for the study sites. Litter moisture was measured through oven drying the litter $\left(65^{\circ} \mathrm{C}\right)$ till a constant weight was reached, and weight difference between dry and wet litter was recorded. Thereby, litter moisture was calculated.

\subsection{Aboveground and Belowground Biomass and C Stock}

Two internationally accepted biomass regression equations (Brown et al., 1989; Anderson \& Ingram, 1998) were applied to calculate aboveground biomass stock using $\mathrm{DBH}$. Thus, an equation developed for dry forests with annual rainfall < $1500 \mathrm{~mm} ; \mathrm{B}=\exp (-1.996+2.32 \times \mathrm{InD}) ; \mathrm{R}^{2}=0.89$ (Brown et al., 1989) was used, where $\mathrm{B}$ and $\mathrm{D}$ are biomass and $\mathrm{DBH}$, respectively. The equation used for calculation of aboveground biomass was $\mathrm{B}=$ $\exp (-2.134+2.530 \times \operatorname{In}(\mathrm{D}))$ for wet zone forest (Anderson \& Ingram, 1998).

According to IPCC guidelines for national greenhouse gas inventories (IPCC, 2006), aboveground C stock of tropical forests is calculated as Biomass $\times 0.49$ (Hughes et al., 2000). Aboveground to belowground biomass ratio, and hence its C ratio, for tropical rain forests (annual rainfall $>2000 \mathrm{~mm}$ ) and moist deciduous forests (annual rainfall between 1000 - $2000 \mathrm{~mm}$ ) was found to be 0.2 (Mokany et al., 2006). Therefore, belowground biomass or $\mathrm{C}$ content is calculated as aboveground biomass or $\mathrm{C} \times 0.2$.

\subsection{Climatic, Soil, and Plant Relationships}

Plant, soil and climatic data of the two forests were pooled and analyzed for detecting grouping of variables responsible for plant CS using Principal Factor Analysis (PFA). The main applications of factor analytical techniques are to reduce the number of variables and to detect structure in the relationships among variables (i.e. to classify variables) (De Genus \& Denys, 2004). Therefore, factor analysis is applied as a data reduction and structure detection method. In data analysis, first, Principal Factor Analysis (PFA) was performed and factor plots were constructed to identify highly correlated variables clustering on the plot (Vereecken \& Herbst, 2004). Varimax rotation was applied to rotate the factor structure. Then, the correlated variables were used in multiple regression analysis using MaxR for selection of variables to enter the equation. In addition, T-test was used to compare means and simple regression analysis was performed to establish univariate relationships found in data analysis. Then diagrammatical models were developed to represent relationships of the above factors.

The data pooling is justifiable as plant CS is governed basically by physico-chemical parameters, but not by forest types etc. (Hessen et al., 2004; Toledo et al., 2010). For example, the same forest type (e.g. montane forests) existing in different regions have different plant $\mathrm{C}$ stocks, mainly due to different physico-chemical parameters (Keith et al., 2009). The pooling also helped to have a sufficient data-set for the analysis.

\section{Results}

Our results showed that the soil moisture, $\mathrm{NH}_{4}^{+}-\mathrm{N}$, soil organic carbon (SOC) and total $\mathrm{N}$ contents were higher in the wet zone forest than the dry zone forest (Table 1). In the dry zone forest $\mathrm{NO}_{3}^{-}-\mathrm{N}$ content and bulk density were higher than the wet zone forest. In the wet zone forest, aboveground biomass (201 t/ha) and belowground biomass (48 t/ha) C stocks were significantly high compared to the dry zone forest (60 t/ha and $17 \mathrm{t} / \mathrm{ha}$, respectively). There was a higher amount of fine root biomass and floor litter $\mathrm{C}$ stock in the dry zone forest than in the wet zone forest. Total ecosystem C stock of the wet zone forest (ca. $361 \mathrm{t} / \mathrm{ha}$ ) was significantly higher ( $p \leq$ 0.05) than the dry zone forest (ca. $176 \mathrm{t} / \mathrm{ha}$ ).

The soil $\mathrm{C}$ fractions in the dry zone forest and the wet zone forest were dominated by fulvic fraction followed 
Table 1. Initial soil properties and carbon stocks of the dry zone forest and the wet zone forest.

\begin{tabular}{ccc}
\hline Parameter & Dry Zone Forest & Wet Zone Forest \\
\hline Soil properties & & $18.2 \pm 1.4$ \\
Moisture (\%) & $10.3 \pm 4.5$ & $5.78 \pm 0.26$ \\
$\mathrm{pH}$ & $6.19 \pm 0.38$ & $0.173 \pm 0.034$ \\
$\mathrm{NH}_{4}^{+}-\mathrm{N}(\mu \mathrm{g} / \mathrm{g})$ & $0.029 \pm 0.007$ & $0.049 \pm 0.008$ \\
$\mathrm{NO}_{3}^{-}-\mathrm{N}(\mu \mathrm{g} / \mathrm{g})$ & $0.182 \pm 0.013$ & $1.58 \pm 0.15$ \\
SOC (\%) & $1.48 \pm 0.25$ & $0.138 \pm 0.08$ \\
Total N (\%) & $0.097 \pm 0.023$ & $1.27 \pm 0.15$ \\
Bulk density (g/cm $\left.{ }^{3}\right)$ & $1.4 \pm 0.28$ & $201.0(55.6 \%) \mathrm{a}$ \\
Carbon stock (t/ha) & $60.2(34.2 \%) \mathrm{b}$ & $48.0(13.3 \%) \mathrm{a}$ \\
Above ground biomass C stock & $16.9(9.6 \%) \mathrm{b}$ & $249(68.9 \%) \mathrm{a}$ \\
Below ground biomass C stock & $77(43.8 \%) \mathrm{b}$ & $2.4(0.66 \%) \mathrm{a}$ \\
Total biomass C stock & $2.7(1.53 \%) \mathrm{a}$ & $4.85(1.34 \%) \mathrm{a}$ \\
Fine root biomass C stock & $4.47(2.54 \%) \mathrm{a}$ & $5.73(1.58 \%) \mathrm{b}$ \\
Annual aboveground biomass increment & $4.72(2.68 \%) \mathrm{a}$ & $2.01(0.55 \%) \mathrm{b}$ \\
Litter fall C stock & $2.36(1.34 \%) \mathrm{a}$ & $108(29.9 \%) \mathrm{a}$ \\
Floor litter C stock & $94(53.3 \%) \mathrm{b}$ & $361 \mathrm{a}$ \\
\hline Total soil C stock & $176 \mathrm{~b}$ & \\
\hline
\end{tabular}

Mean \pm SE. Means in the same column followed by the same letter are not significantly different at 5\% probability level, according to T-test. Prediction of total biomass of forest stands calculated using biomass regression equation. i.e., $\mathrm{B}=\exp (-1.996+2.32 \times$ In (D)) for dry forest (Brown et al., 1989) $\mathrm{B}=\exp (-2.134+2.530 \times$ In (D)) for moist forest (Anderson \& Ingram, 1998). (B = Biomass Stock, D = DBH). Values within parentheses are magnitudes of component $\mathrm{C}$ stocks as a percentage of total ecosystem $\mathrm{C}$ stock.

by humic fraction then free soil litter. Fulvic fraction represented ca. 50\% of total C, ca. 30\% humic fraction and ca. 20\% free soil litter (Figure 3). From January to August, there was a declining trend of free soil litter resulting in a simultaneous increase of fulvic fraction. Compared to the wet zone forest, the dry zone forest consists of higher amount of fulvic fraction. There was an accumulation of free soil litter fraction with a decline of fulvic fraction. There was a considerable decrease of humic fraction in the wet zone forest during January-February and then humic fraction increased in the short dry season (April-May). However, in the dry zone forest more humic fraction accumulates in wet season (August-September).

Pooled data of the two forests were analyzed using Principal Factor analysis (PFA) with varimax rotation. A single cluster was separated in the factor plot, which included factors influencing plant biomass $\mathrm{C}$ stocks (Figure 4). The variables included in the same cluster were biomass $\mathrm{C}$, free litter fraction, fulvic fraction, humic fraction, soil moisture, organic C, total litterfall, soil N, alpha index, and rainfall. Multiple regression analysis of the variables yielded the following relationship.

$$
\text { Plant biomass C stock }=-3238+6.81 \mathrm{FLF}-8.54 \mathrm{HF}+2215 \mathrm{SM}+13463 \mathrm{MD} ; \mathrm{R}^{2}=0.94
$$

where FLF, HF, SM and MD are free litter fraction, humic fraction, soil moisture, and McIntosh distance (MD), respectively. In addition, a positive correlation for soil nitrogen and McIntosh distance (MD) was resulted in second order regression model (Figure 5). Finally, we developed two models using the most influential factors, which contribute to CS in the dry zone forest and the wet zone forest (Figure 6 and Figure 7).

\section{Discussion}

Soil moisture is fundamental to plant growth, because water exchange is an important complement to the forest C cycle (Chapin et al., 2009). Depending on the availability, labile C constrains microbial action that determines 


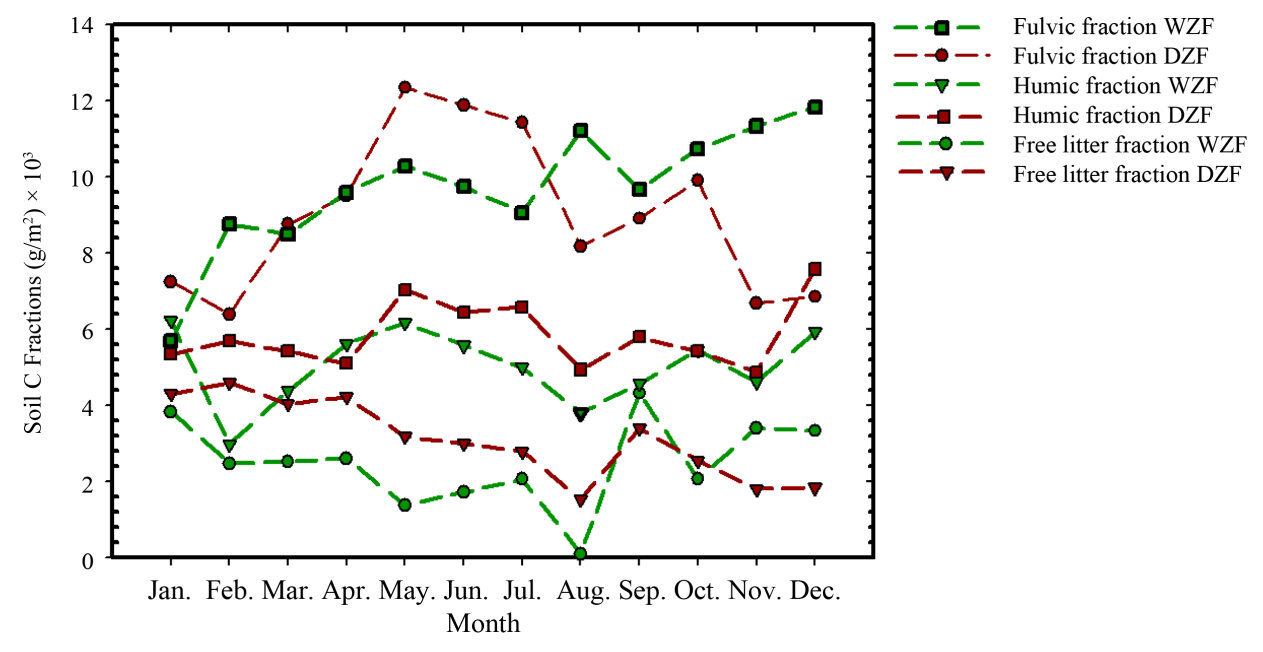

Figure 3. Variation of soil carbon fractions of the dry zone forest and the wet zone forest within an annual cycle.

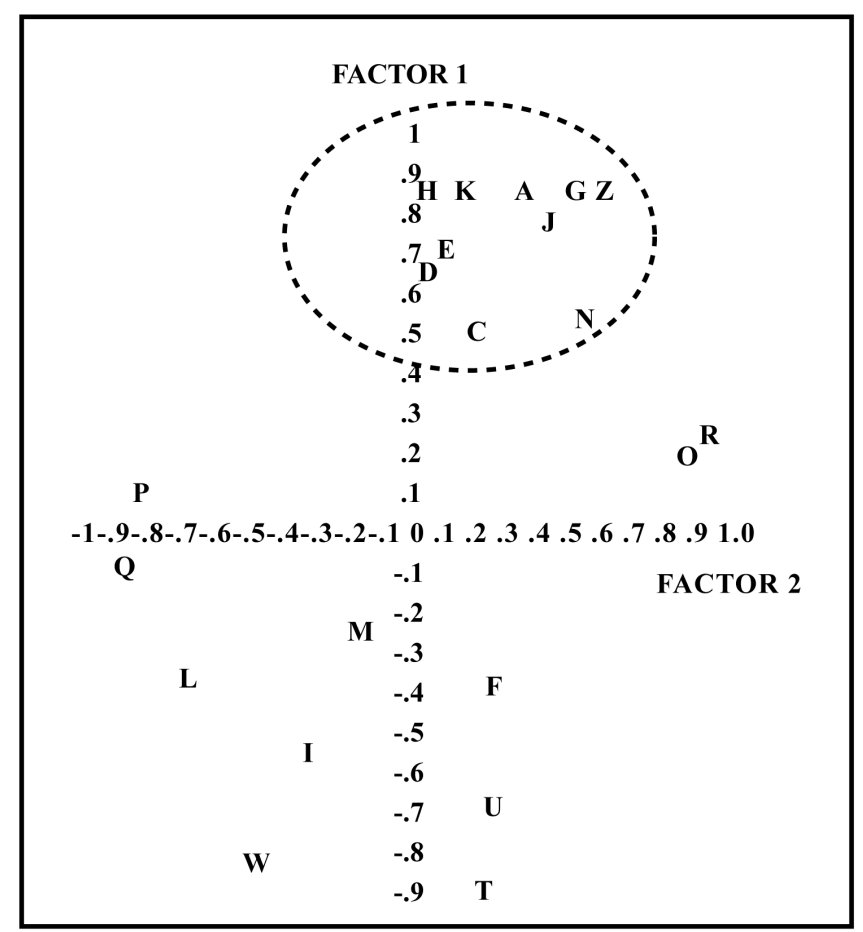

Figure 4. Factor plot of variables responsible for plant biomass carbon sequestration of the dry and wet zone forests (pooled data). Highly correlated variables clustered on the plot are encircled with a dotted circle. $\mathrm{A}=$ biomass carbon, $\mathrm{B}=$ biomass stock, $\mathrm{C}=$ free litter fractions, $\mathrm{D}=$ fulvic fractions, $\mathrm{E}=$ humic fractions, $\mathrm{F}=$ fine root biomass, $\mathrm{G}=$ soil moisture, $\mathrm{H}=$ soil organic carbon, $\mathrm{I}=$ total floor litter, $\mathrm{J}=$ total litterfall, $\mathrm{K}=$ soil nitrogen, $\mathrm{L}=$ soil $\mathrm{pH}, \mathrm{M}=\mathrm{C} / \mathrm{N}$ ratio, $\mathrm{N}=$ alpha index, $\mathrm{O}=$ Shannon J, P = berger-parker dominance, $\mathrm{Q}=$ simpons diversity, $\mathrm{R}=$ hill number (Species richness), $\mathrm{S}=$ mackintosh distance $(\mathrm{U}), \mathrm{T}=$ mackintosh evenness $(\mathrm{E}), \mathrm{U}=$ total tree density, $\mathrm{V}=$ total basal area, $\mathrm{W}=$ minimum temperature, $\mathrm{X}=$ maximum temperature, $\mathrm{Y}=$ average temperature, $\mathrm{Z}=$ rainfall and alliance variables.

nutrient cycling (Ekberg et al., 2007; Kuzyakov et al., 2007), which in turn limits plant growth. On the other hand, aboveground floristic composition affects the accumulation of labile C fractions (Bardgett et al., 2005). Clark et al. (2003) reported that species composition and element inputs fundamentally alter the relationship 


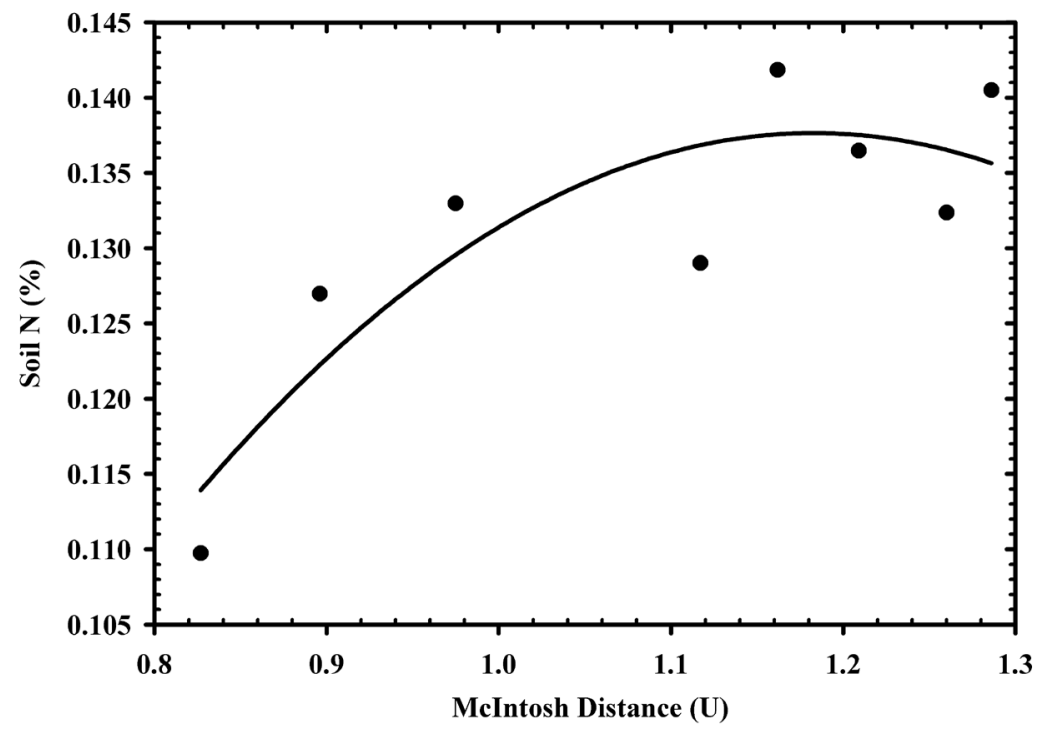

Figure 5. Relationship between Mackintosh distance $(\mathrm{U})$ and soil nitrogen of the dry and wet zone forests (pooled data). Equation for the model is $\mathrm{Y}=0.14 /(1+3841 \mathrm{e}-11.7 \mathrm{x})$ and $\mathrm{R}^{2}=0.82$.

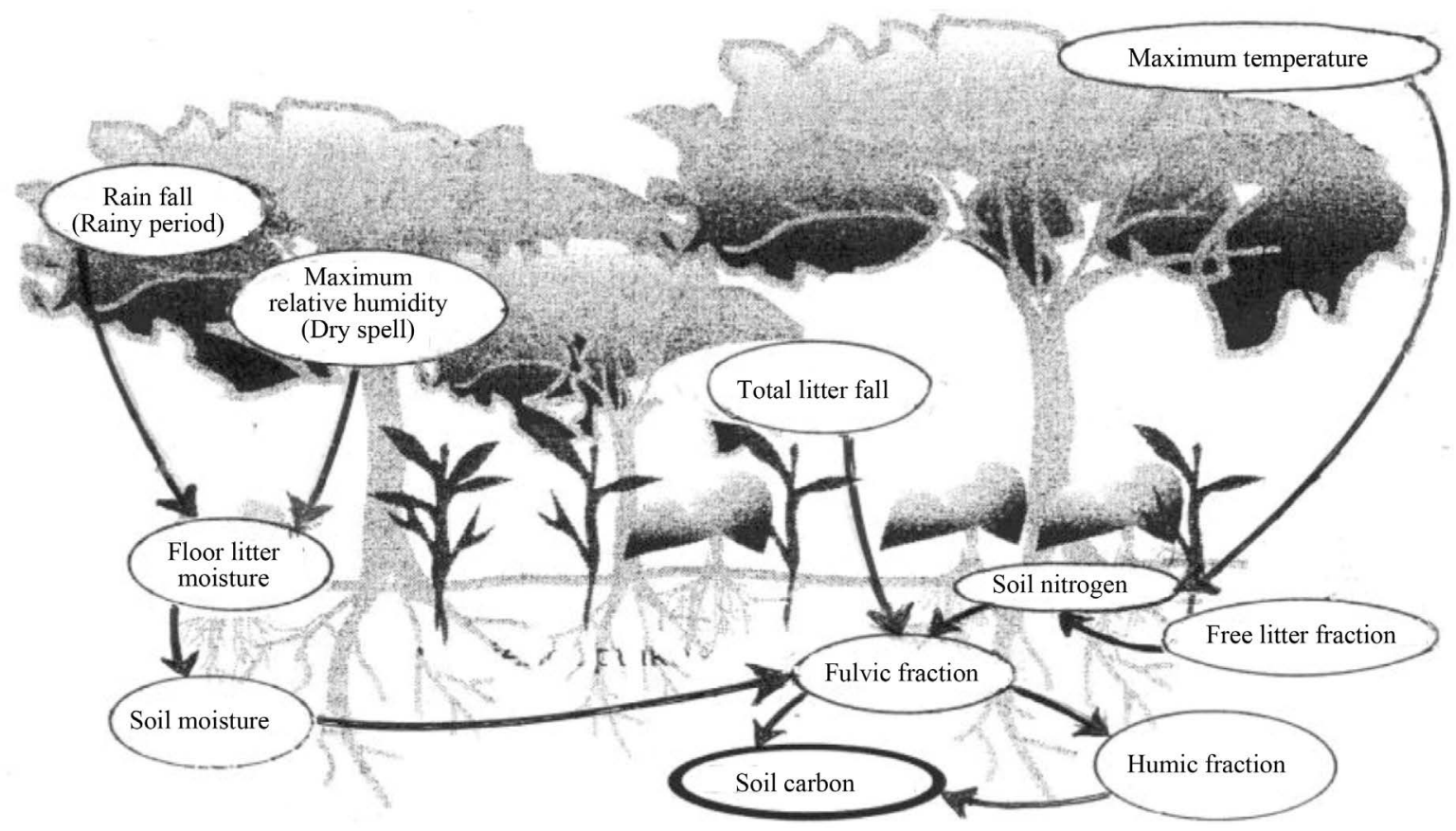

Figure 6. Diagrammatic representation of the network of factors controlling soil carbon sequestration in the dry zone forest. Arrows indicate influences or flows of matter.

between climate drivers and ecosystem $\mathrm{C}$ dynamics. This could be due to acceleration of soil microbial action with the availability of soil moisture (Lupwayi et al., 2010).

The most abundant plants in the dry zone of Sri Lanka belong to Fabaceae, which can fix nitrogen using symbiotic association. This could be a reason for high $\mathrm{NO}_{3}^{-}-\mathrm{N}$ content in the dry zone forest soil. The reason for higher fine root growth of dry zone forest is for up-taking water efficiently and the survival successional stager's process (in five months dry spell). The distribution of aboveground and belowground biomass is largely influenced by the plant species and growth forms within spatial gradients in soil moisture and other edaphic conditions (Wang et al., 2008). 


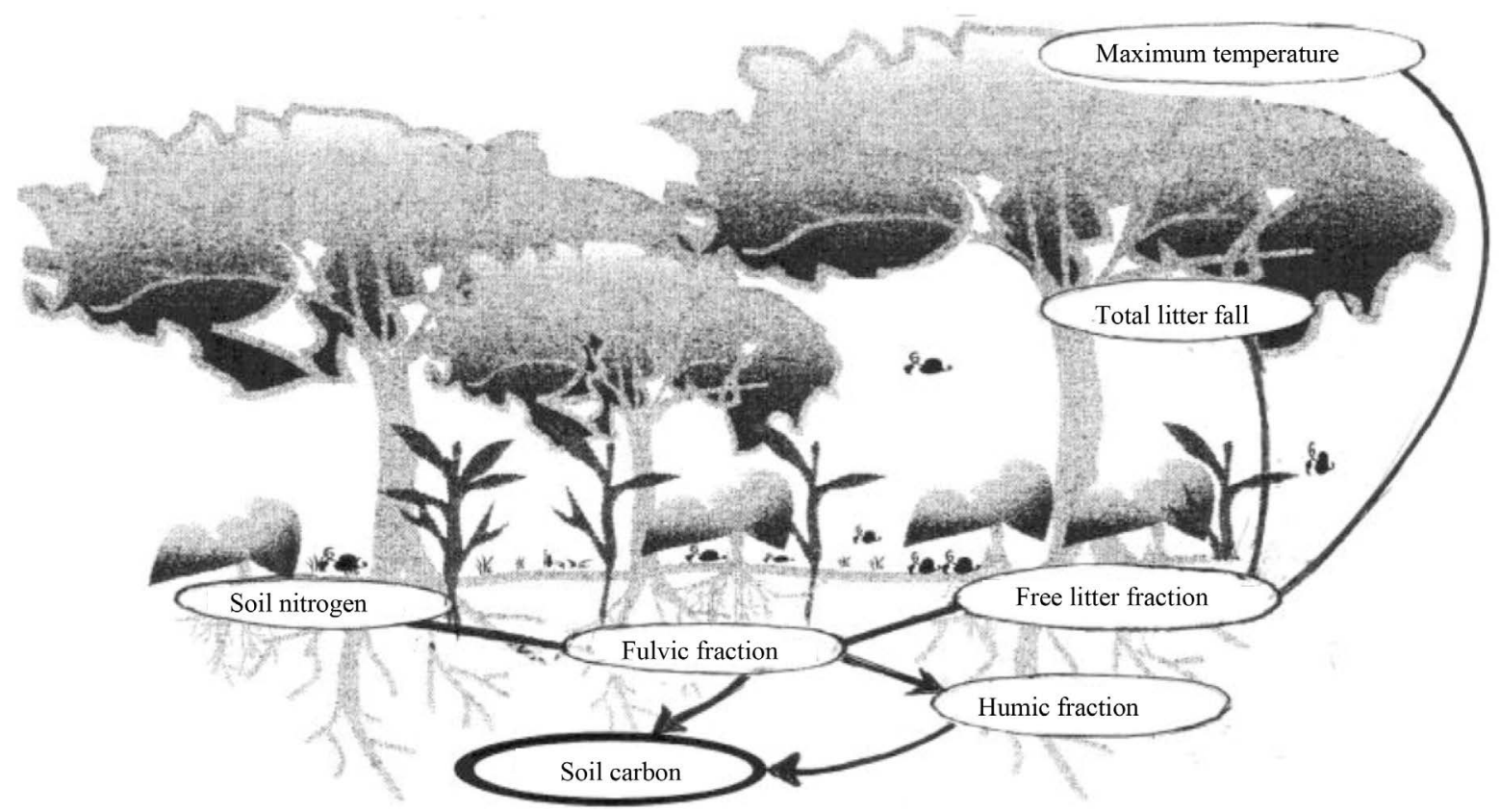

Figure 7. Diagrammatic representation of the network of factors controlling soil carbon sequestration in the wet zone forest. Lines represent interactions whereas arrows indicate influences or flows of matter.

Leaf and root litter are major nutrient suppliers to natural forest ecosystems. Wet zone plants have broad leaves and therefore they contributed more leaf litter in the soil. Litter decomposition in the wet zone is high due to high moisture content, which aids in active microbial growth. This leads to an increase of soil C stock in the wet zone forest. In contrast, the dry zone forest showed a high accumulation of floor litter C stock, which resulted in defoliation due to environmental stress and due to less microbial decomposition in five months dry spell (Table 1). However, soil C stock in the dry zone forest was less compared to the wet zone forest resulting in a reduced rate of decomposition of organic matter, which produces less $\mathrm{CO}_{2}$. Comparatively higher plant biomass $\mathrm{C}$, total soil $\mathrm{C}$, and ecosystem $\mathrm{C}$ were recorded at the wet zone forest due to high soil moisture and labile organic matter fraction (Table 1 ).

There was an increased production of fine roots in the dry zone forest compared to the wet zone forest attributed to a simultaneous leaf flush on the canopy with a green-up (Kuruppuarachchi et al., 2013). Fine root growth in the dry zone forest seemingly was fuelled by $\mathrm{N}$ supply from the organic matter through microbial growth and action utilizing labile soil $\mathrm{C}$ and the water supply through the atmosphere-floor litter-soil continuum (Figure 6). The fine root growth in the dry zone forest indicates that the plants have developed a survival mechanism in response to dryness to absorb water as efficiently as possible.

McIntosh distance (U) determines plant species richness. When the index is high, the species richness is also high. Thus, high values of the index contribute to high plant biomass $\mathrm{C}$ stocks. However, the biomass $\mathrm{C}$ accumulation is soil nutrient-limited, particularly N (Cleveland \& Townsend, 2006). Apparently, this has been overcome by increased soil $\mathrm{N}$ accumulation, possibly through biological nitrogen fixation under high species richness and abundance (i.e. McIntosh index) (Figure 5). In addition, McIntosh distance (U) index showed the significant positive relationship with soil N. Generally, soil N is limited in tropical forests (Cleveland \& Towsend, 2006). High species richness and spatial distribution (i.e. high McIntosh index) would reduce the $\mathrm{N}$ limitation.

Janzen et al. (1997) and Weil and Magdoff (2004) reported that stable C fractions establish a relatively larger pool of $C$ than the labile fractions in the soils as shown by our results (Figure 3). This is attributable to the decomposition and transformation of the free soil litter to the fulvic fraction (Zalamea et al., 2007; Gulde et al., 2008). This could be due to fresh C supply from floor litter layer that dissolved into organic C, which helps rapidly decompose humic fractions by active microbial growth after the rains (Qualls, 2005; Johnson et al., 2007; Müller et al., 2009).

Organic matter fractions sequestered in the two forests showed that all three fractions were significantly higher 
in the wet zone forest than the dry zone forest (Table 1). Thus, the wet zone forest soil had a larger $\mathrm{C}$ storage than that of the dry zone forest soil. It may be due to absence of moisture limitation soils in the wet zone forests as dry zone forest. Previous studies reported that soil C storage in tropical forests ranges between 90 - $200 \mathrm{t}$ C/ha (Brown \& Lugo, 1984; Kimble et al., 1990; Amundson, 2001; Lewis et al., 2009). Therefore, it is apparent that the soil $\mathrm{C}$ sequestration capacity of the two forests stands lies in the lower range of the tropics. The SOC results suggest that the dry zone forest needs excess water to maintain stable carbon fraction hence CS and wet forest prefer water stress for soil CS.

Results of biotic/abiotic relationships towards CS indicates that plant biomass C stock is governed by labile (FLF) and stable (HF) C fractions, soil moisture and plant species diversity (MD) of the selected forests. The size of stable $\mathrm{C}$ pool i.e. humic fraction governs plant growth, because a larger pool in the soil restricts the availability of $\mathrm{C}$ sources to microbes, as reflected by negative relationship in the above equation. Soil moisture is the fundamental need for plant growth (Chapin et al., 2009). Labile fraction (FLF) of forest soil drives nutrient cycling, which is important for microbial action (Ekberg et al., 2007). A large stable C pool would restrict the supply of the labile $\mathrm{C}$ source to microbes, as reflected by the negative relationship with biomass $\mathrm{C}$ accumulation. The soil fulvic fraction was found to act as a focal point of interacting with or influencing the other variables such as soil N, free litter fraction, humic fraction etc. Thus, these variables determine soil CS of the wet zone forest and the dry zone forest (Figure 6 \& Figure 7). Our study revealed that air temperature and labile fraction (FLF) play a vital role in determining soil N, as also shown by Singh and Kashyap (2007) and Rice (2006), respectively.

The dry zone forest CS model showed that maximum relative humidity and rainfall during dry and wet periods, respectively, governed soil moisture through an atmosphere-floor litter-soil continuum (Figure 6). Soil moisture directly influenced the fulvic fraction in the forest soil. The model developed for the dry zone forest indicated that the control of CS is more complicated than that of the wet zone forest (Figure 6 and Figure 7).

It is projected that climate change will affect the dry zone more (the northeast and the east) with a decline in rainfall and an increase in temperature, evapotranspiration and soil moisture deficit (De Silva, 2006; De Silva et al., 2007; Eriyagama et al., 2010). Similarly, it has been predicted that there would be a northward shift of tropical wet forest into areas currently occupied by tropical dry forest (Somaratne \& Danapala, 1996). Thus, it is clear that more interactions with climatic parameters would arise in the dry zone forests in the future climatic change scenarios. As such, the dry zone forests are seen to be more climatic sensitive and vulnerable than the wet zone forests.

\section{Conclusion}

This study showed that the humic fraction is more stable and a mirror of the free litter and the fulvic fractions, which contributes ca. 30\% of the total soil C. With availability of soil moisture, free litter fraction transformed into fulvic fraction resulted in ca. $20 \%$ and ca. $50 \%$ of the total soil C respectively. The study suggests that storing SOC in deeper soil layers would be an effective management strategy for CS, which transforms free litter fraction to fulvic and humic fractions, while reducing $\mathrm{CO}_{2}$ emission though microbial activities. Fine root biomass accumulation in the dry zone forest aids in efficiency of water absorption of plants especially in the dry spell. Consequently, leaf flushing and canopy green-up were observed in the dry spell of the dry zone forest to facilitate root growth. The dry zone forest showed that maximum relative humidity is the most influential factor to govern CS, through an atmosphere-floor litter-soil continuum. Carbon sequestration process in the dry zone would be more vulnerable to climatic change in future due to less rainfall and hence moisture scarcity in the soil.

\section{Acknowledgements}

This research study was carried out at the Microbial Biotechnology Unit (MBU), Institute of Fundamental Studies (IFS), Kandy, Sri Lanka. We would like to thank the relevant authorities of the IFS for providing us excellent working facilities and we are very grateful to Ms. Kumuduni Karunaratne and Mr. K.K. Karunadasa, IFS Technical Officers, for providing invaluable support in the laboratory as well as in the field.

\section{References}

Amundson, R. (2001). The Carbon Budget in Soils. Annual Review of Earth and Planetary Sciences, 29, 535-562.

http://dx.doi.org/10.1146/annurev.earth.29.1.535 
Anderson, J. M., \& Ingram, J. S. I. (1998). Tropical Soil Biology and Fertility: A Handbook of Methods (2nd ed.). CABI International, Wallingford, UK.

Bandaratillake, H. M. (1996). Eucalyptus Plantations in Sri Lanka. In M. Kashio, \& K. White (Eds.), Environmental, Social, Economic, and Policy Issues (pp. 193-212). Bangkok: FAO Regional Office for Asia and the Pacific, RAP Publication 2.

Bardgett, R. D., Bowman, W. D., Kaufmann, R., \& Schmidt, S. K. (2005). A Temporal Approach to Linking Aboveground and Belowground Ecology. Trends in Ecology \& Evolution, 20, 635-641. http://dx.doi.org/10.1016/j.tree.2005.08.005

Beedlow, P. A., Tingey, D. T., Phillips, D. L., Hogsett, W. E., \& Olszyk, D. M. (2004). Rising Atmospheric $\mathrm{CO}_{2}$ and Carbon Sequestration in Forests. Frontiers in Ecology and the Environment, 2, 315-322.

de Bello, F., Lavorel, S., Díaz, S., Harrington, R., Cornelissen, J. H. C., Bardgett, R. D., Berg, M. P., Cipriotti, P., Feld, C. K., Hering, D., da Silva, P. M., Potts, S. G., Sandin, L., Sousa, J. P., Storkey, J., Wardle, D. A., \& Harrison, P. A. (2010). Towards an Assessment of Multiple Ecosystem Processes and Services via Functional Traits. Biodiversity and Conservation, 19, 2873-2893.

Bremner, J. M., \& Tabatabai, M. A. (1972). Use of an Ammonia Electrode for Determination of Ammonium in Kjeldahl Analysis of Soils. Communications in Soil Science and Plant Analysis, 3, 159-165. http://dx.doi.org/10.1080/00103627209366361

Brown, S. A., Gillespie, J. R., \& Lugo, A. E. (1989). Biomass Estimation Methods for Tropical Forests with Applications to Forest Inventory Data. Forest Science, 35, 881-902.

Brown, S., \& Lugo, A. E. (1984). Biomass of Tropical Forest: A New Estimate Based on Forest Volume. Science, 223, 1290-1293. http://dx.doi.org/10.1126/science.223.4642.1290

Chapin, F. S., McFarland, J., McGuire, A. D., Euskirchen, E. S., Ruess, R. W., \& Kielland, K. (2009). The Changing Global Carbon Cycle: Linking Plant-Soil Carbon Dynamics to Global Consequences. Journal of Ecology, 97, 840-850. http://dx.doi.org/10.1111/j.1365-2745.2009.01529.x

Clark, D. A., Brown, S., Kicklighter, D. W., Chambers, J. Q., Thomlinson, J. R., Ni, J., \& Holland, E. A. (2001). Net Primary Production in Tropical Forests, an Evaluation and Synthesis of Existing Field Data. Ecological Applications, 11, 371384. http://dx.doi.org/10.1890/1051-0761(2001)011[0371:NPPITF]2.0.CO;2

Clark, D. A., Piper, S. C., Keeling, C. D., \& Clark, D. B. (2003). Tropical Rain Forest Tree Growth and Atmospheric Carbon Dynamics Linked to Inter Annual Temperature Variation during 1984-2000. Proceedings of the National Academy of Sciences of the United States of America, 100, 5852-5857. http://dx.doi.org/10.1073/pnas.0935903100

Cleveland, C. C., \& Townsend, A. R. (2006). Nutrient Additions to a Tropical Rain Forest Drive Substantial Soil Carbon Dioxide Losses to the Atmosphere. Proceedings of the National Academy of Sciences of the United States of America, 103, 10317-10321. http://dx.doi.org/10.1073/pnas.0600989103

Cramer, L. H. (1993). A Forest Arboretum in the Dry Zone. Kandy: Institute of Fundamental Studies.

De Deyn, G. B., Cornelissen, J. H. C., \& Bardgett, R. D. (2008). Plant Functional Traits and Soil Carbon Sequestration in Contrasting Biomes. Ecology Letters, 11, 516-531. http://dx.doi.org/10.1111/j.1461-0248.2008.01164.X

De Genus, F., \& Denys, D. (2004). Pitfalls in Factor Analytic Techniques. The American Journal of Psychiatry, 161, 579-580. http://dx.doi.org/10.1176/appi.ajp.161.3.579-a

De Silva, C. S. (2006). Impacts of Climate Change of Water Resources in Sri Lanka. 32nd WEDC International Conference, Colombo, 13-17 November 2006, 289-295.

De Silva, C. S., Weatherhead, E. K., Knox, W. J., \& Rodriguez-Diaz, J. A. (2007). Predicting the Impacts of Climate Change-A Case Study of Paddy Irrigation Water Requirements in Sri Lanka. Agricultural Water Management, 93, 19-29. http://dx.doi.org/10.1016/j.agwat.2007.06.003

Ekberg, A., Buchmann, N., \& Gleixner, G. (2007). Rhizospheric Influence on Soil Respiration and Decomposition in a Temperate Norway Spruce Stand. Soil Biology and Biochemistry, 39, 2103-2110. http://dx.doi.org/10.1016/j.soilbio.2007.03.024

Eriyagama, N., Smakhtin, V., Chandrapala, L., \& Fernando, K. (2010). Impacts of Climate Change on Water Resources and Agriculture in Sri Lanka: A Review and Preliminary Vulnerability Mapping. International Water Management Institute, IWMI Research Report No. 135.

Evans, J. L., Fernandez, I. J., Rustad, L. E., \& Norton, S. A. (2001). Method for Evaluating Carbon Fractions in Forest Soils: A Review. Maine Agricultural and Forestry Experiment Station Technical Bulletin, 178, 1-42.

Green, M. J. B. (1990). IUCN Directory of South Asian Protected Areas. Cambridge, UK: IUCN.

Gulde, S., Chung, H., Amelung, W., Chang, C., \& Six, J. (2008). Soil Carbon Saturation Controls Labile and Stable Carbon Pool Dynamics. Soil Science Society of America Journal, 72, 605-612. http://dx.doi.org/10.2136/sssaj2007.0251

Hairiah, K., Sulistyani, H., Suprayogo, D., Widianto, L., Purnomosidh, P., Widodo, R. H., \& Van Noordwijk, M. (2006). 
Litter Layer Residence Time in Forest and Coffee Agroforestry Systems in Sumberjaya, West Lampung. Forest Ecology and Management, 224, 45-55. http://dx.doi.org/10.1016/j.foreco.2005.12.007

Hessen, D. O., Ågren, G. I., Anderson, T. R., Elser, J. J., \& de Ruiter, P. C. (2004). Carbon Sequestration in Ecosystems: The Role of Stoichiometry. Ecology, 85, 1179-1192. http://dx.doi.org/10.1890/02-0251

Hodge, A., Stewart, J., Robinson, D., \& Fitter, A. H. (2000). Competition between Roots and Soil Micro-Organisms for Nutrients from Nitrogen-Rich Patches of Varying Complexity. Journal of Ecology, 88, 150-164.

http://dx.doi.org/10.1046/j.1365-2745.2000.00434.x

Hughes, R. F., Kauffman, J. B., \& Jaramillo-Luque, V. J. (2000). Ecosystem-Scale Impacts of Deforestation and Land Use in a Humic Tropical Region of Mexico. Ecological Applications, 10, 515-527. http://dx.doi.org/10.1890/1051-0761(2000)010[0515:ESIODA]2.0.CO;2

IPCC (2001). Climate Change 2001: Impacts, Adaptation, and Vulnerability, Summary for Policymakers. A Report of Working Group II of the Intergovernmental Panel on Climate Change. Geneva: IPCC.

IPCC (2006). IPCC Guidelines for National Greenhouse Gas Inventories. H. S. Eggleston, L. Buendia, K. Miwa, T. Ngara, \& K. Tanabe (Eds.). Hayama: Institute for Global Environmental Strategies, IPCC.

Janzen, H. H., Campbell, C. A., Gregorich, E. G., \& Ellerf, B. H. (1997). Soil Carbon Dynamics in Canadian Agroecosystems. In R. Lal, J. M. Kimble, R. F. Follett, \& B. A. Stewart (Eds.), Soil Process and the Carbon Cycle (Advance in Soil Science) (pp. 57-80). Boca Raton, FL: CRC Press.

Johnson, J. M. F., Barbour, N. W., \& Weyers, S. L. (2007). Chemical Composition of Crop Biomass Impactsits Decomposition. Soil Science Society of America Journal, 71, 155-162. http://dx.doi.org/10.2136/sssaj2005.0419

Keith, H., Mackey, B. G., \& Lindenmayer, D. B. (2009). Re-Evaluation of Forest Biomass Carbon Stocks and Lessons from the World's Most Carbon-Dense Forests. Proceedings of the National Academy of Sciences of the United States of America, 106, 11635-11640. http://dx.doi.org/10.1073/pnas.0901970106

Kimble, J., Cook, T., \& Eswaran, H. (1990). Organic Matter in Soils of the Tropics. Proceeding of the Symposium: Characterization and Role of Organic Matter in Different Soils. 14th International Congress of Soil Science, Kyoto, 12-18 August 1990, 250-258.

Kuruppuarachchi, K. A. J. M., Seneviratne, G., \& Madurapperuma, B. D. (2013). Drought Induced Fine Root Growth and Canopy Green-Up of Tropical Dry Zone Vegetations in Sri Lanka. Journal of Tropical Forestry and Environment, 3, $17-23$.

Kuzyakov, Y., Hill, P. W., \& Jones, D. L. (2007). Root Exudates Components Change Litter Decomposition in a Simulated Rhizosphere Depending on Temperature. Plant Soil, 290, 293-305. http://dx.doi.org/10.1007/s11104-006-9162-8

Legg, C., \& Jewell, N. (1995) A 1:50,000 Forest Map of Sri Lanka: The Basis for a National Forest Geographic Information System. Battaramulla: The Forester, Forestry Information Service, Sri Lanka Forest Department.

Lewis, S. L., Lopez-Gonzalez, G., Sonké, B., Affum-Baffoe, K., Baker, T. R., Ojo, L. O., Phillips, O. L., Reitsma, J. M., et al. (2009). Increasing Carbon Storage in Intact African Tropical Forest. Nature, 457, 1003-1006.

http://dx.doi.org/10.1038/nature07771

Lupwayi, N. Z., Grant, C. A., Soon, Y. K., Clayton, G. W., Bittman, S., Malhi, S. S., \& Zebarth, B. J. (2010). Soil Microbial Community Response to Controlled-Release Urea Fertilizer under Zero Tillage and Conventional Tillage. Applied Soil Ecology, 45, 254-261. http://dx.doi.org/10.1016/j.apsoil.2010.04.013

Mokany, K., Raison, J. R., \& Prokushkin, A. S. (2006). Critical Analysis of Root: Shoot Ratios in Terrestrial Biomes. Global Change Biology, 12, 84-96. http://dx.doi.org/10.1111/j.1365-2486.2005.001043.x

Müller, M., Alewell, C., \& Hagedorn, F. (2009). Effective Retention of Litter-Derived Dissolved Organic Carbon in Organic Layers. Soil Biology \& Biochemistry, 41, 1066-1074. http://dx.doi.org/10.1016/j.soilbio.2009.02.007

Naoum, S., \& Tsanis, I. K. (2003). Temporal and Spatial Variation of Annual Rainfall on the Island of Crete, Greece. Hydrological Processes, 17, 1899-1922. http://dx.doi.org/10.1002/hyp.1217

NPPD (National Physical Planning Department) (2002). National Physical Planning Policy, Final Document. Battaramulla: National Physical Planning Department, Ministry of Western Region, Government of Sri Lanka.

Panabokke, C. R. (1996). Soils and Agro-Ecological Environments of Sri Lanka. Colombo: Natural Resources, Energy and Science Authority of Sri Lanka.

Petkovsek, G., \& Mikos, M. (2005). Estimating the R Factor from Daily Rainfall Data in the Sub-Mediterranean Climate of Southwest Slovenia. Hydrological Sciences Journal, 49, 20-23.

Premaratne, S., \& Premalal, G. G. C. (2005). Country Pasture/Forage Resource Profiles, Sri Lanka. http://www.fao.org/ag/agp/agpc/doc/Counprof/srilanka/srilanka.htm

Pushpakumara, D. K. N. G. P., \& Hitinayake, H. M. G. S. B. (2001). Invasive Tree Species in Udawattakele Forest Reserve. Sri Lankan Biodiversity Review, 1, 33-63. 
Qualls, R. G. (2005). Biodegradability of Fractions of Dissolved Organic Carbon Leached from Decomposing Leaf Litter. Environmental Science \& Technology, 39, 1616-1622. http://dx.doi.org/10.1021/es049090o

Ramachandran, A., Jayakumar, S., Haroon, R. M., Bhaskaran, A., \& Arockiasamy, D. I. (2007). Carbon Sequestration: Estimation of Carbon Stock in Natural Forests Using Geospatial Technology in the Eastern Ghats of Tamil Nadu, India. Current Science, 92, 323-331.

Ratnayake, R. R., Seneviratne, G., \& Kulasooriya, S. A. (2007). A Modified Method of Weight Loss on Ignition to Evaluate Soil Organic Matter Fractions. International Journal of Soil Science, 2, 69-77. http://dx.doi.org/10.3923/ijss.2007.69.73

Rice, C. W. (2006). Organic Matter and Nutrient Dynamics. Encyclopedia of Soil Science: Second Edition. Boca Raton, FL: Taylor and Francis Group.

Rossi, J., Govaerts, A., de Vos, B., Verbist, B., Vervoort, A., Poesen, J., Muys, B., \& Deckers, J. (2009). Spatial Structures of Soil Organic Carbon in Tropical Forests: A Case Study of Southeastern Tanzania. Catena, 77, 19-27. http://dx.doi.org/10.1016/j.catena.2008.12.003

Senarathna, P. M. (2005). Sri Lankawe Wananthara (1st ed.). Nugegoda: Sarasavi Publishers.

Singh, J. S., \& Kashyap, A. K. (2007). Variations in Soil N-Mineralization and Nitrification in Seasonally Dry Tropical Forest and Savanna Ecosystems in Vindhyan Region, India. Tropical Ecology, 48, 27-35.

Somaratne, S., \& Dhanapala, A. H. (1996). Potential Impacts of Global Climate Change on Forest Distribution in Sri Lanka. Water, Air, and Soil Pollution, 92, 129-135. http://dx.doi.org/10.1007/978-94-017-1053-4_12

Toledo, M., Poorter, L., Claros, M. P., Alarcón, A., Balcázar, J., Leaño, C., Licona, J. C., Llanque, O., Vroomans, V., Zuidema, P., \& Bongers, F. (2010). Climate Is a Stronger Driver of Tree and Forest Growth Rates than Soil and Disturbance. Journal of Ecology, 99, 254-264. http://dx.doi.org/10.1111/j.1365-2745.2010.01741.X

Vereecken, H., \& Herbst, M. (2004). Statistical Regression. In Y. Pachepsky, \& W. J. Rawls (Eds.), Developments in Soil Science Series (pp. 3-19). Amsterdam: Elsevier BV. http://dx.doi.org/10.1016/s0166-2481(04)30001-2

UNFCCC (1997). Kyoto Protocol. Geneva: UNFCCC. http://unfccc.int/kyoto_protocol/items/2830.php

Walkley, A. (1947). A Critical Examination of a Rapid Method for Determining Organic Carbon in Soils: Effect of Variations in Digestion Conditions and of Inorganic Soil Constituents. Soil Science, 63, 251-264. http://dx.doi.org/10.1097/00010694-194704000-00001

Walkley, A., \& Black, I. A. (1934). An Examination of the Degtjareff Method for Determining Soil Organic Matter and a Proposed Modification of the Chromic Acid Titration Method. Soil Science, 37, 29-38. http://dx.doi.org/10.1097/00010694-193401000-00003

Wang, C., Long, R., Wang, Q., Jing, Z., Du, Y., \& Cao, G. (2008). Effects of Soil Resources on Species Composition, Plant Diversity, and Plant Biomass in an Alpine Meadow Qinghai-Tibetan Plateau. Israel Journal of Ecology and Evolution, 54, 205-222. http://dx.doi.org/10.1080/15659801.2008.10639613

Wedathanthri, H. P., \& Hitinayake, H. M. G. S. B. (1999). Invasive Behavior of Myroxylonbalsamum at Udawattakele Forest Reserve. 5th Annual Forestry and Environment Symposium: Challengers in Natural Resource Conservation in the 21st Century, Department of Forestry and Environmental Science, University of Sri Jayewardenepura, Nugegoda, 10-11 December 1999, 14.

Weil, R. R., \& Magdoff, F. (2004). Soil Organic Matter in Sustainable Agriculture. Department of Natural Resource Sciences and Landscape Architecture. Boca Raton, FL: CRC Press.

Zalamea, M., González, G., Ping, C.-L., \& Michaelson, G. (2007). Soil Organic Matter Dynamics under Decaying Wood in a Subtropical Wet Forest: Effect of Tree Species and Decay Stage. Plant Soil, 296, 173-185.

http://dx.doi.org/10.1007/s11104-007-9307-4 